Portland State University

PDXScholar

1971

\title{
"Follow through" Services for Child Abuse Cases
}

Marguerite Matusak

Portland State University

Follow this and additional works at: https://pdxscholar.library.pdx.edu/open_access_etds

Part of the Social Work Commons

Let us know how access to this document benefits you.

\section{Recommended Citation}

Matusak, Marguerite, "'Follow through" Services for Child Abuse Cases" (1971). Dissertations and Theses. Paper 1769.

https://doi.org/10.15760/etd.1768

This Thesis is brought to you for free and open access. It has been accepted for inclusion in Dissertations and Theses by an authorized administrator of PDXScholar. Please contact us if we can make this document more accessible: pdxscholar@pdx.edu. 


\title{
"FOLLOW THROUGH" SERVICES \\ FOR \\ CHILD ABUSE CASES
}

\author{
by \\ MARGUERITE MATUSAK
}

A Research Practicum Report submitted in partial fulfillment of the requirements for the degree of

MASTER IN SOCIAL WORK

Portland State University

1971 


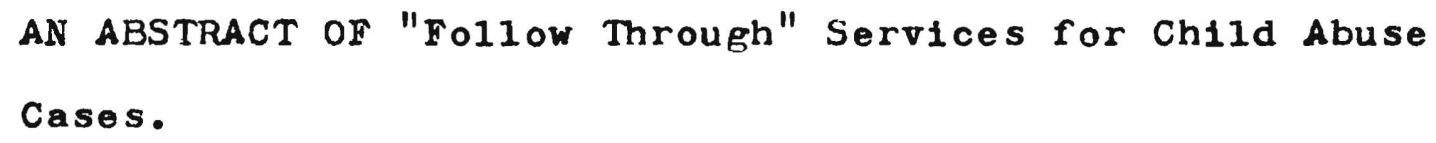

The Child Abuse Committee in the University of Oregon Medical School was formed in 1966 to help the staff reoognize child abuse cases and do something about them. This research report is an evaluation of their effectiveness as an agency attempting to prevent further injury to the children involved. Indications are that timely intervention and subsequent "follow through" have been helprul to the families and improved the situation substantially. A study of the abuse cases seen through the hospital for the calendar years of 1569 and 1970 revealed that almost all of the children from these study years who were seriously injured came from two parent homes with their natural parents. Comparisons between the two study years indicate a more comprehensive handing of suspected abuse cases in 1970 with corresponding improvement in outcome. 
TABLE OF CONTENTS

\section{PAGE}

LIST OF TABLES . . . . . . . . . . . 111

TEXT

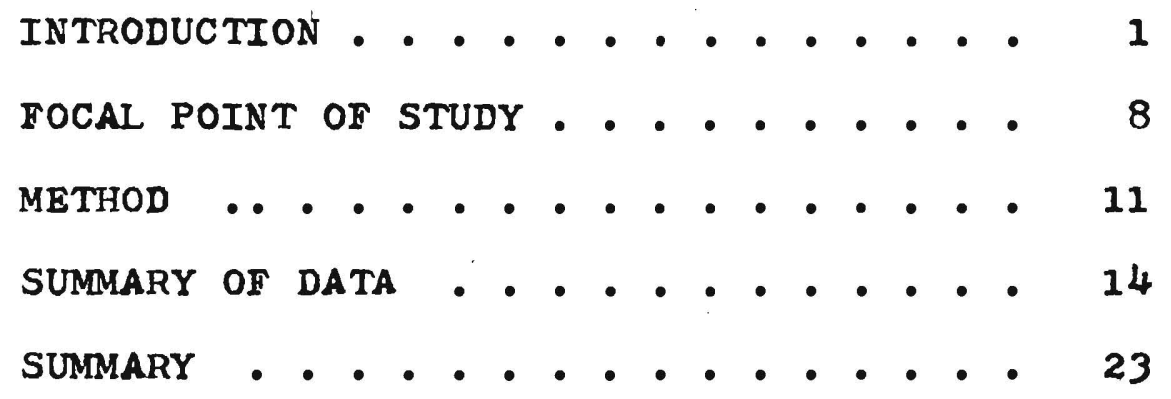

BIBLIOGRAPHY • • • • . . . . . • 27 


\section{LIST OF TABLES}

TABLE

PAGE

I Age Distribution ............ 14

II Serious Injury and Family Make-Up -

In Frequencies . . . . . . . 15

III Children Made Court Wards as a Result

of Report of Injury . . . . . . 16

IV Children Removed as a Result of

Hospitalization (= More Serious

Injury) • • • • • . . . . . . 17

V Families Receiving Help as a Result of

Child Being Remored . . . . . . 18

VI Families Who Have Improved Their Situation

Through Agency Help... . . . 20

VII Seriousness of the Injury Related to

Situation Outcome . . . . . . . 22 


\section{INTRODUCTION}

Child abuse and child neglect are subjects that have always been close to my conscience. As a human being and as a child welfare worker I have of ten wondered if there is really any sure way of offering a child protection of 11 fe and $11 \mathrm{mb}$ In his own home. To one familiar with the field, the facts are grim. Innocent children daily become victims of their own parent's frustrations and hostilities at everyday 1iving. 1 The magnitude of the picture becomes overwhelining when we realize that these abusive parents were frequently victims themselves as children. 2

On this premise every child-victim of today could become a potential child abuser to come. Obviously something must be done in every community to stop the spread of this vicious cycle. There are several different ways of approaching the problem, but all experts agree that immediate intervention

${ }^{1}$ John A. Brown and Robert Daniels, "Some Observations on Abusive Parents", Child Welfare, XLVII (February 1968), 90-91; Betty Johnson and Harold Morse, "Injured Children and Their Parents", Children, 15 (July-August 1968), 150; Ray T. Helfer and $C$. Henry Kompe, eds., The Battered Child, 111.

${ }^{2}$ Serapio R. Zalba, "The Abused Child, II A Typology for classification and Treatment", Social Work, 12 (1967), 72; Jean Rubin, "The Need for Intervention", Pubilc Weifare, 24 (1966), $231-232$. 
to protect the child is essential. $3 *$

Who should provide the protective services to children is a frequently too-much argued point. Within the past fow years the hospital staff at the University of Oregon Medical School realized the great number of battered and neglected children they were acturily seoing. In some cases the same children reappeared time and again with injuries that strong1y suggested abuse within their own home. Two children from our 1969 cases had been seen repeatedly in the out-patient department for unexplained injuries; and in one of these, battering was suspected in the years of 1966,1967 , and 1968 as well as 1969. Around four or five years ago the hospital, as an institution, found they were not providing neoded services to these children in trying to prevent a repetition of such injury and neglect.

Dr. Richard W. Olmsted, Professor and Chairman of Pediatrics Department noted that the doctors (residents and interns) had a real reluctance to become involved in child abuse cases and to diagnose them as batterings. He felt this was due partly to their fear of appearing in court and testifying on such a complaint, as well as their lack of experience in this area. Dr. Olmsted saw the need for a standardized procedure on how to recognize and how to handle suspected cases.

3alba, op cit, 70; Ernest A. Herre, "A Community Mobilizes to Protect Its Children", Public Welfare, 24 (1966), 96-97; Rubin, op cit, 231-232; Vincent J. Fontana, "An Insidious and Disturbing Medical Entity", Public Weifare, 24 (1966), 238; Betty Johnson and Harold.A. Morse, "Injured Children and Their Parents", Children, 15 (1968), 152. 
Terming it a "mechanism with visibility" for the staff, the first Child Abuse Committeo was formed in about 1966.

This first group was sma11--members included Dr. O1msted; Miss Betty Weible, Nursing Supervisor; Mrs. Shirley Buxton, Social Worker; and Mrs. Mary Erlandson, Public Health Nursing Co-ordinator. The group acted in an advisory capacity, and encouraged the resident in charge of the case to bring to them any suspected case of abuse. The Child Abuse Committeo would then help him to know what to do at that point. Moetings wero on an ad hoc basis and the group got together only as needed. In reflecting on the earlier years, Dr. Olmsted foels the committee did a reasonably good job but they still lacked any ability to follow up on the cases, nor were they able to communicate with the agencies in the community working with these families so that their activitios could be co-ordinated. The hospital personnel also lacked knowledge of what resources were available for these children and their families within this area. Perhaps even more important, the hospital needed the co-operation of the Juvenile Court in providing protection for those children who were in serious danger from their own ramilies.

A very clear example of this occurred in one of our 1969 cases when battering was strongly suspected in the case of a

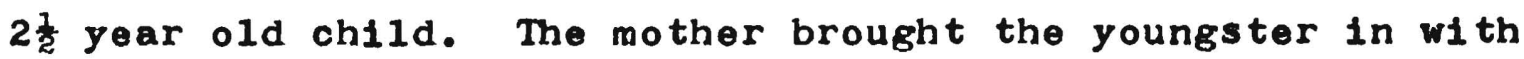
a fairly serious scrotum injury and obvious puncture wounds under all the fingernails. She claimed the child had a 
"bleeding disorder" which had been diagnosed in a Texas hospital. When no bleeding disorder was found after extensive tests, and an old fracture of the tibia was seen on the x-ray, the doctors called the Texas hospital and learned that the child had been considered "battered" by them. The mother had explained the child's injuries as a "blood disorder" to them but when they ruled this out and confronted her with suspected abuse, she took the child and fled the state. When the medical school doctor and social worker attempted to discuss the new injuries with the mother, she again took the child against medical advice and disappeared. We have no knowledge of where this family is at present or of the youngster's condition.

Under the new arrangement, were such a situation to occur, the hospital would request a temporary custody order from the Juvenile Court pending a full investigation by the court of suspected abuse, and could thereby offer the child some protection while all the facts were substantiated. Parents would not be told of the hospital's suspicions until they had temporary custody. Providing the order were granted by the judge, the parents could not remove the child from the hospital until permission was granted by the court. Since July of 1970, the Child Abuse Committee has expanded both in sizo and services. A regular agenda has beon established with meetings held regularly every Monday afternoon. In the event an emergency arises between the weekly meetings, an ad hoc group is called and a decision is made 
by them. With the addition of Mrs. Joan Hazelrigg as the regular Social Worker assigned to the committeo, procedures have changed somewhat.

Dr. Olmsted notes that the doctors are still reluctant to commit themselves on child abuse, and if it is brought to their attention they are often quick to deny it and be quite resistant. For this reason, the doctors no longer present cases to the committee, but if they suspect abuse they call the Social Worker and she presents the case, complete with social history, to the committee for their opinion. If the committee feels there is strong evidence pointing toward abuse or neglect, a decision is made on how to proceed (possibly through Juvenile Court, intensive work with the family, obtaining a home evaluation, or perhaps further medical examination); the case is then continued until the next weok while the recommendations are carried out. The case is kept on the active agenda until it is resolved to the satisfaction of the members; it is then mored to the inactive 1ist where it is usually reviewed every three months for any new developments until such time that it can safely be closed. The Social Worker also reviews all children's cases involving fractures, burns, subdural hematomas, and ingestions with regard to possible abuse.

At the present time the committee is made up of the following members: Dr. O1msted; Dr. William N. Clark, Director of In-Patient Pediatrics; Dr. Emily Tufts, Liaison-Coordinator for Pediatric Out-Patient Department; Mrs. Joan 
Hazelrigg, Social Worker; Mrs. Helen Erlandson, Public Health Nursing Co-ordinator; Miss Mary Amdal1, Psychiatric Nurso; and Mr. Duane McNannay, Juvenile Court Counselor. For the past school year I have had the privilege of sitting with this group and participating in their activities.

Each member contributes something to the committeeDr. Olmsted, Dr. Clark and Dr. Tufts interpret medical data and express their medical opinion. Dr. Tufts will often reexamine youngster; Mrs. Hazelrigg has contact with the family and other social resources for the family; Mrs. Erlandson arranges for Public Health nurses to evaluate the home situation or provide home nursing services as needed, as well as to report back to the committeo; Miss Amdall observes the youngster in the hospital as well as the parent-child interaction; Mr. McNannay provides the very important service of Ilaison between the hospital and the court.

The working relationship between these two agencies is excellent, and Mr. Mclannay provides the committee with advice on how to proceed, as well as up to date information on cases that the court has jurisdiction over.

With the addition of Mrs. Hazelrigg, the committee has been able to $100 k$ at cases of "fallure to thrive" on suspected neglect that cannot be attributed to organic problems. This is a very important area as it often includes serious neglect, and often leads to discovery of cases of child abuse. Dr. Kempe from Denver has been quoted as saying that as high as one-third of abuse cases can come in first diagnosed as 
"failures to thrive". 4 From our 1970 cases the "failures to thrive" represented $30 \%$ of the 27 cases studied.

A typical case along this line is one where the child is admitted for poor weight gain, lack of normal development mentally and physically and general developmental retardation. After admission, no organic iliness is found, but the youngster gains weight rapidly and shows considerable progress developmentally in a brief period of time. Sometimes old scars are found on the child's body, and previous unsuspected traumas are located on the x-rays. With a picture such as this, the child's case is presented to the committee and appropriate steps are taken to protect the child while an investigation is made of the total situation. But more often, no actual evidence of injury is located and it is only the fact that the child thrives in the hospital and not at home that makes the comnittee suspicious that the child is neglected. At this point the committeo would request a home evaluation with follow-up help to the family for the problems. If, in spite of help, the situation is again repeated and the child is in physical danger, the case is referred to the court.

4 In a speech delivered to "The Battered Child Symposium", University of Colorado, Denver, November 19-21, 1970. 
TOCAL POINT OF THE STUDY

In order to take a good look at the workings of the Child Abuse Committeo, all the cases of ohild abuse and severe neglect that were seen at the hospital in the calendar years of 1969 and 1970 were reviewed. The total number was 31 cases in 1969 and 59 cases in 1970.

For purposes of this study these numbers were then broken down into those cases for which the hospital should or did take responsibility for follow up help. Throughout this study, the term "rollow through" will be used to indicate professional help recelved by families from various agencies in the community following the incident of abuse, and usually directly related to it.

The medical records of all the cases were read, evaluated, and basic data was gathered on them. They were then separated on the basis of hospital responsibility for "follow through". The totals were broken down as follows:

$\begin{array}{lcc} & 1969 & 1970 \\ \text { Total cases } & 31 & 59 \\ \text { Study cases } & 19 & 27 \\ \text { Not our cases } & 12 & 32\end{array}$

The hospital defines their responsibility for providing "follow through" as those cases in which the abuse or gross neglect is identified by their staff in the process of providing regular medical care; if the case had been theirs prior to the 
injury; or if the case had been referred to this hospital

from another medical facility as an in-patient after having been diagnosed as a "battered child".

The hospital does provide the "battered child examination" for other agencies in the community such as Women's Protective Division, Juvenile Court, Public Welfare, and the District Attorney's office. These cases do not become "ours" unless the hospltal had been providing care to the youngster prior to that time. The hospital sees one of its responsibilities toward the child-victim as attempting to prevent a repeat injury.

Through the mechanism of the Child Abuse Committee, the hospital attempts to provide protection for the child, as well as finding resources within the community to provide counseling and help for the abusing family.

In choosing the calendar years of 1969 and 1970 we hoped to see a difference in the outcome of the cases. Up to and Including 1969, the Child Abuse Committee operated on an ad hoc basis, meeting only when necessary and providing intermittent service. Their attempts at engaging community agencies in providing "follow through" to the families were often weak and unheoded.

During 1970 the Child Abuse Committee changed from a more or less ad hoc group to a much firmer body with clear responsibilities toward co-ordinating attempts to help the family. In the opinion of this researcher, there were some significant differences between the two years, with 1970 
showing much better "follow through" and subsequent improvement within the families. Some might argue that the period studied was not long enough to establish whether this trend would continue. The only logical answer to this would be a continuation of the study to include the next fow years. 
METHOD

After selection of the cases for study, data were gathered on each from the medical record.

I looked at the age of the child at the time of admission; type of injury; whether hospitalized; whether a Report of Injury was filed with the Oregon State Board of Health; any notation of any agency involvement with the family (whether law enforcement or social agency). The hospital does not always learn who is the perpetrator of the abuse, so this information was not included.

In attempting to evaluate the outcome of the abuse and severe neglect cases seen in the hospital, I tried to ascertain the present situation of the child and his family. No attempt was made to contact the family directly, nor to obtain their impressions of how they were managing. All data regarding this were obtained from professional people working with the families or aware of their situation. Some families I was never able to locate, and so their outcome can only be termed "unknown". 5

Each case was checked through the resources of the Juvenile Courts (Multnomah, Clackamas, Washington and Marton counties): Public Welfare (Multnomah, Clackamas, Yambi11,

5 This number represents 9 out of 19 families in 1969, and 6 out of 27 families in 1970. 
Clatsop, and Marion counties); Public Health Nursing (Multnomah, Clatsop, Clackamas and Coos counties); Women's Protective Division; and Multnomah County Sheriff's office. Through these agencies I was able to determine fairly well the number of families receiving help at this time. In some cases the families were being followed by an agency such as Juvenile Court or Public Welfare and also recelving specialized treatment in clinics such as Child Guidance, Delaunay Institute, etc.

With this kind of contact with other agencies in the area we were able to determine, as well as possible, whether a repeat incident of abuse had come to anyone's attention. In evaluating the outcome of each case I looked at several things such as:

Was the child removed as a result of the injury? Is he a ward of the court? Where is the ohild at present? Is the family receiving help (and from whom)? Prosent situation of the family?

From this information I judged whether the situation had improved or not, based on the situation at the time of the Injury.

I received my information on the families directly from the person within the agency who had responsibility for the case (if there was one). I felt that all of those I talked with were honest in discussing their positive reelings and their concern regarding their families. Interestingly, almost every worker made a similar comment about the fact that 
the abuse (or neglect) was only one of the problems that the particular family raced. 6 They cited such other pressures as marital discord, financial problems, inadequate personality, and mental illness. 7 All agencies and the personnel contacted were very co-operative in providing the information requested.

${ }^{6}$ John A. Brown and Robert Daniels, op c1t., 92-93.

7 This follows closely the observations of other researchers in the field. In particular the article by John A. Brown and Robert Daniels, op cit., 94; Zalba, op oit., 72; Betty Johnson and Harold Morse, op cit., 150-151. 


\section{SUMMARY OF DATA}

The age distribution of the children in the study ranged from $3 \frac{1}{2}$ weeks to 13 years, but birth to three years represents the majority of cases in both study years (seo below). 8 While serious injury occurred at many age levels it often appeared in the very young child, perhaps due to their physical vulnerability.

TABLE I

AGE DISTRIBUTION

\begin{tabular}{|c|c|c|c|c|}
\hline & \multicolumn{2}{|c|}{1969} & \multicolumn{2}{|c|}{1970} \\
\hline & Number & Percent & Number & Percent \\
\hline $\begin{array}{l}\text { Under } 1 \text { year } \\
1-2 \\
2-3 \\
3-4 \\
4-5 \\
5-6 \\
6=12 \\
\text { over } 12\end{array}$ & $\begin{array}{l}5 \\
4 \\
4 \\
0 \\
2 \\
2 \\
2 \\
0 \\
\end{array}$ & $\begin{array}{r}26 \\
21 \\
21 \\
0 \\
11 \\
11 \\
10 \\
0 \\
\end{array}$ & $\begin{array}{r}10 \\
8 \\
2 \\
2 \\
0 \\
1 \\
3 \\
1 \\
\end{array}$ & $\begin{array}{r}37 \\
30 \\
7 \\
7 \\
0 \\
4 \\
11 \\
4 \\
\end{array}$ \\
\hline TOTALS & 19 & $100 \%$ & 27 & $100 \%$ \\
\hline
\end{tabular}

Both study years revealed the majority of the cases to be from families with two parents. This ranged from 58\% in 1969 to $84 \%$ in 1970. An interesting relationship developed

8 These figures also agree with other studies oompleted on the subject. Notes Jean Rubin, op oit., 231; Vincent Fontana, op cit., 237 . 
between the seriousness of the injury and the family make-up. From our cases we found the injured child was more 1ikely to receive a serious injury in a two parent household.

\section{TABLE II}

\section{SERIOUS INJURY AND FAMILY}

MAKE-UP - IN FREQUENCIES

1969

Serious injury

Non-serious injury

1970

Serious injury

Non-serious injury

1969 and 1970 Combined

Serious injury

Non-serious injury $\begin{array}{cc}\text { Two } & \text { One } \\ \text { Parents } & \text { Parent }\end{array}$

6

5

$\begin{array}{rl}15 & 2 \\ 6 & 2\end{array}$

* Tro additional serious injuries never firmly established as abuse.

This relationship approaches statistical significance the 10\% level suggesting that future research may indeod find seriousness of injury associated with family composition. It appears that there may be something about the family interaction in intact families that is more apt to precipitate serious abuse. This led to some speculation that the two parent families might include step-parents but this did not prove to be true. With the exception of one foster family, all the other families from the two year period were natural parents to the abused ohildren.

The type of injury received varied greatly within the scope of this study. The term "serious injury" will refer to those injuries which could in themselves, be life threatening, 
or 1ikely to cause permanent damage, or requiring hospitalization, such as fractures, extensive burns, starvation, etc. Non-serious injuries are such as bruises, contusions, lacerations and sores, usually requiring only out-patient treatment. The hospital was fairly consistent in the percentage of cases which they filed a Report of Injury on. These were $63 \%$ in 1969 and $67 \%$ in 1970 . I looked at the possible connection between court wardship and Report of Injury and found that in 1969 only 50\% of those cases on which reports were f11ed became court wards; but in $1970,61 \%$ of those cases resulted in wardships. The following graph will demonstrate the association.

TABLE III

CHILDREN MADE COURT WARDS AS A RESULT OF REPORT OF INJURY
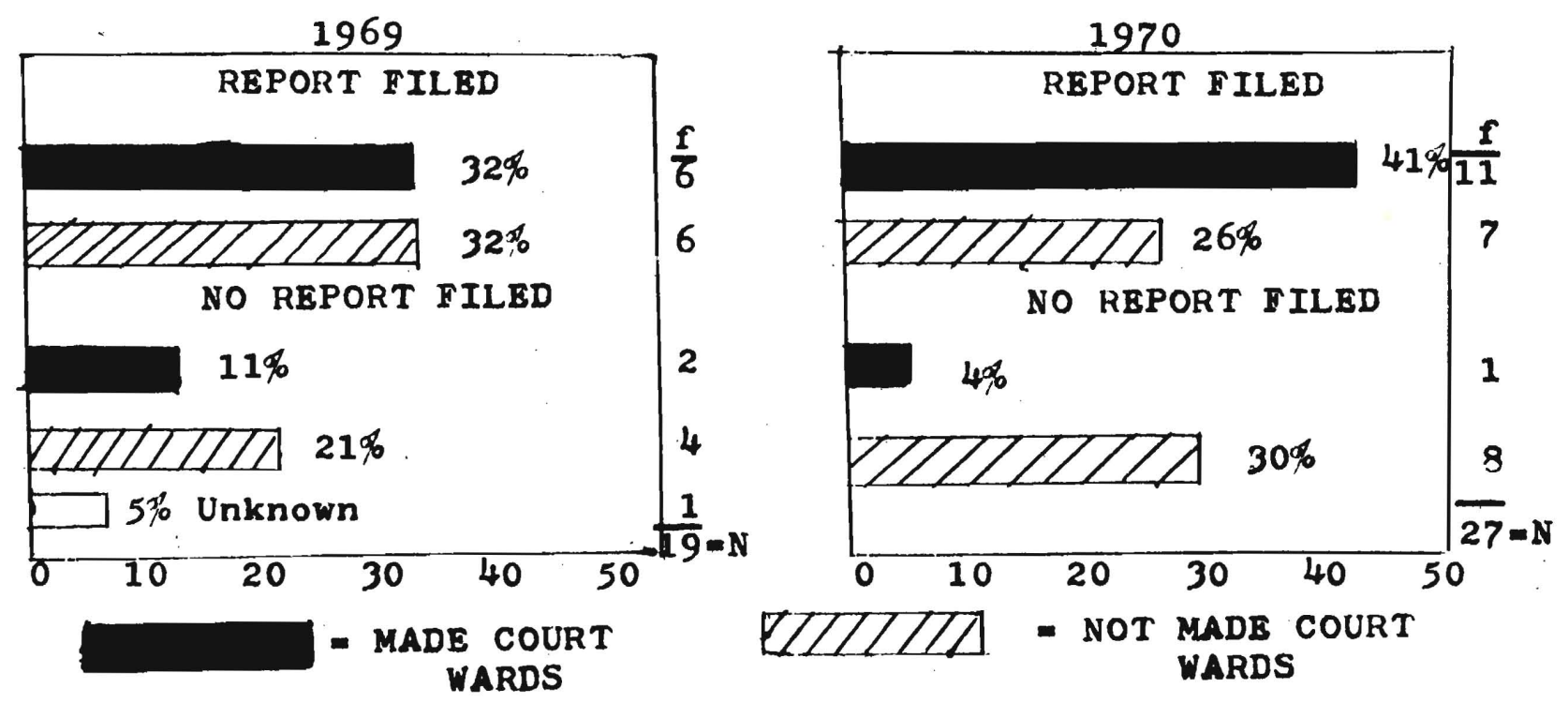

Another way of looking at what happened after the injury or the severe neglect was to compare hospitalizations (= more serious injury) with subsequent removal of the child 
from the home. The breakdown was as follows:

TABLE IV

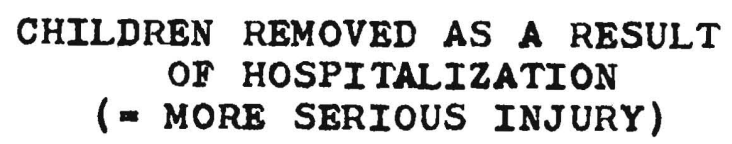

1969

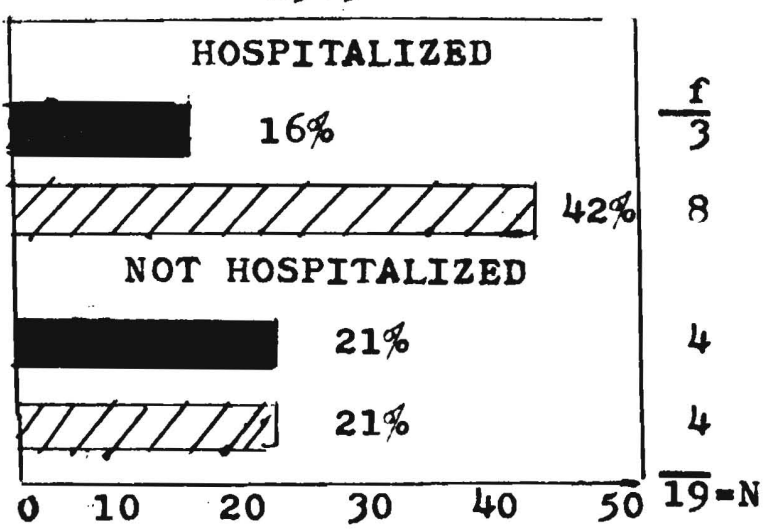

(PERCENT)

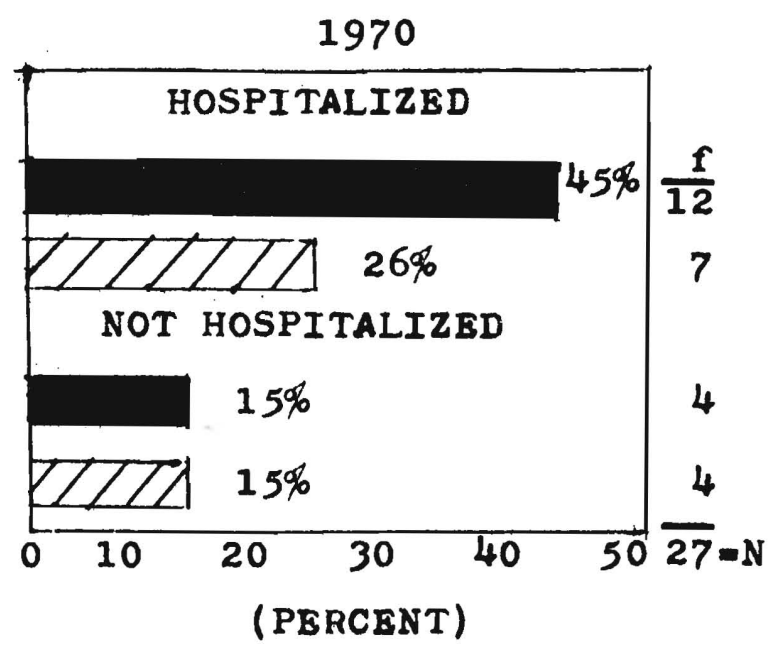

- REMOVED

Q7/7X = NOT REMOVED

An interesting thing occurred in 1969--while $58 \%$ of the study children were hospitalized (those with serious injuries) only $16 \%$ were removed; but a full $21 \%$ were also removed by the court, even though they were not seriously enough injured to be hospitalized.

In the 1970 study children 70\% were hospitalized while only $45 \%$ were removed because of the serious injury. Another $15 \%$ were removed with minor injuries.

Removal of a child is usually a strong impetus for receiving agency help because it is almost always a part of the court order removing the child. This relationship was clear1y demonstrated in both years. 
TABLE V

FAMILIES RECEIVING HELP AS A RESULT

OF CHILD BEING REMOVED

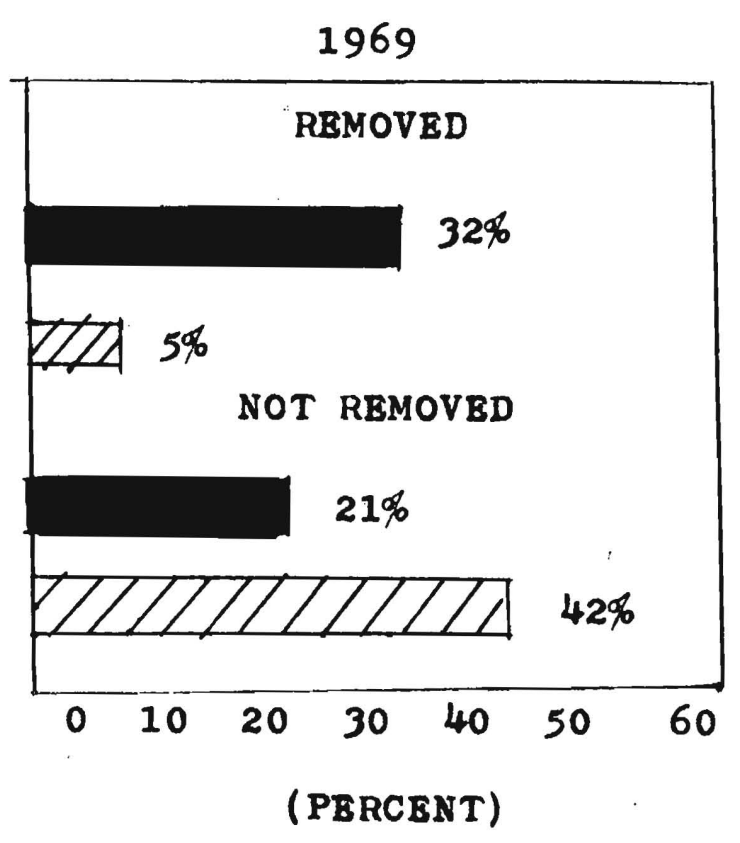

- RECEIVING HELP

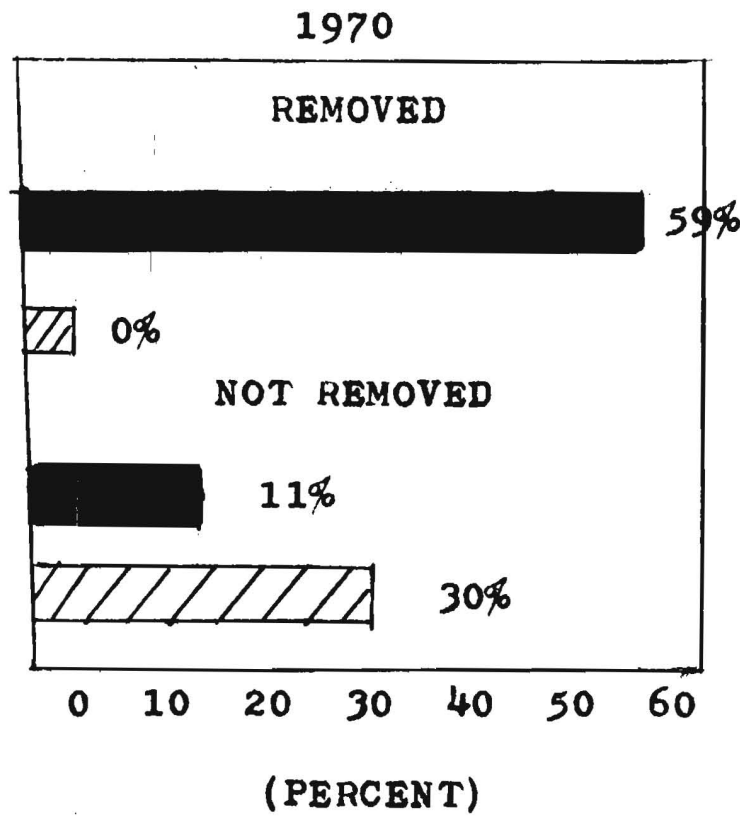

P//A NOT RECEIVING HELP

A large percentage of cases in 1969 (42\%) were considered as not receiving help and the present situation of most of these was simply unknown.

By no means can we hope that all families that are recelving help will improve their situation. This is due to the fact that in almost all the cases studied there were multiple social problems present. To resolve them all would be almost miraculous--so in most cases the caseworkers had to concentrate on the most pressing issues and do the best they could 
with limited goals. 9

With regard to rating improvement, I devised a rating

scale from 1 - 5 as follows:

1 - Total situation notably improved (child is safo and family functioning considerably better).

2 - Child is safe (such as in foster care) family situation same as at time of injury or very questionable.

3 - Repeated incidence of abuse (or neglect).

4 - Unknown (no known contact or whereabouts unknown).

5 - Situation very uncertain (very uncertain of child's safety and family's functioning very precarious even though agency is involved.

One and two were considered as improvements; three and five were seen as not improved and four is in its own category, and not considered good as abusive families are known to avold law enforcement and social agencies rather than work on their problems. 10

overall in the 1969 cases $58 \%$ of the families were receiving help as opposed to $70 \%$ in 1970. Although there is a definite improvement betweon these years we cannot discount the fact that too high a percentage of these cases still avold recelving help by simply disappearing.

9 In some cases these goals would simply be to control the abuse as the family did not have the capacity to substantially change. Please refer to a discussion of the matter in Zalba, op cit.; Brown and Daniels, op c1t., 92,93 and 94; Herre, op cit.; Johnson and Morse, "Injured Children and Their Parents".

${ }^{10}$ Yelaja, "The Concept of Authority and Its Use in Child Protective Service"; Zalba, op cit.; Brown and Daniels, op cit. 
I attempted to break down the overall picture for these two years as follows:

TABLE VI

FAMILIES WHO HAVE IMPROVED THEIR

SITUATION THROUGH AGENCY HELP

1969

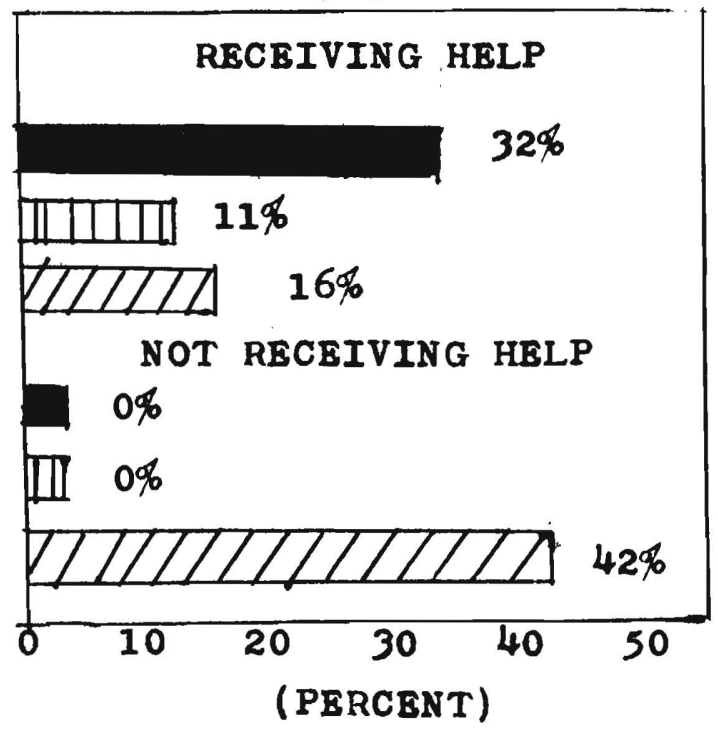

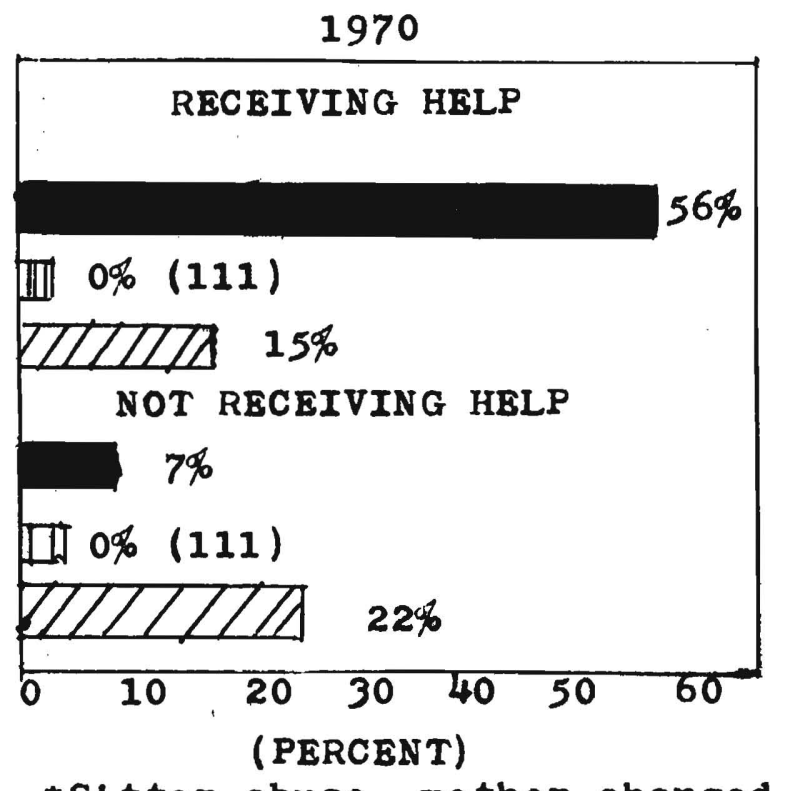

* Sitter abuse--mother changed sitters.

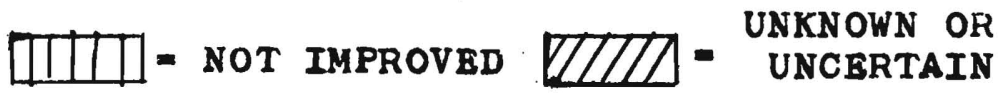

Four cases from the year 1969 appeared again in 1970 with a new incidence of suspected repeated abuse. One of these was definitely later determined as not receiving a new injury, and one other was never confirmed. Still another child from our 1969 cases died while this study was in progress, as a delayed result of serious brain injuries received from her father almost two years earlier.

Interestingly, ho was seon at a private hospital for prior injuries before he came to our attention, but no "follow through" was initiated by them. One can only speculate whether 
removal at the time of the first injuries, along with help to the family, could have spared this youngster's 11 fe.

Fortunately there have been no known repeat incidents of abuse on the 1970 study cases. This is not to say it will not or cannot happen. A greater percentage of them are using agency help, but there is still the unknown to be reckoned with. For those in the study that are receiving help the percentages are much better. of the 19 cases in 1969--ten are receiving help and of these seven are improved; two are uncertain; and one was not improved (child died). In 1970, of the 27 cases, nineteon are receiving help and of these fifteon are improved; four are uncertain, but none are unimproved.

THOSE RECEIVING HELP

$\begin{array}{lcc}\text { Improved } & \frac{1969}{7} & \frac{1970}{15} \\ \begin{array}{c}\text { Unimproved or } \\ \text { uncertain }\end{array} & \frac{3}{10} & \frac{4}{19}\end{array}$

Prediction is a large concern in abuse cases as those professionals involved are always hoping to predict based on known facts of other cases. With this in mind I investigated one relationship between the seriousness of the injury and the outcome. Serious injury represented $48 \%$ in 1969 and $68 \%$ in 1970. A notable improvement in outcome, however, was seen in the 1970 cases, no doubt as an indication that the more serious cases (- hospitalization) received more attention both 
from the hospital and the Juvenile Court. Note the following graph:

TABLE VII

SERIOUSNESS OF THE INJURY RELATED

TO SITUATION OUTCOME
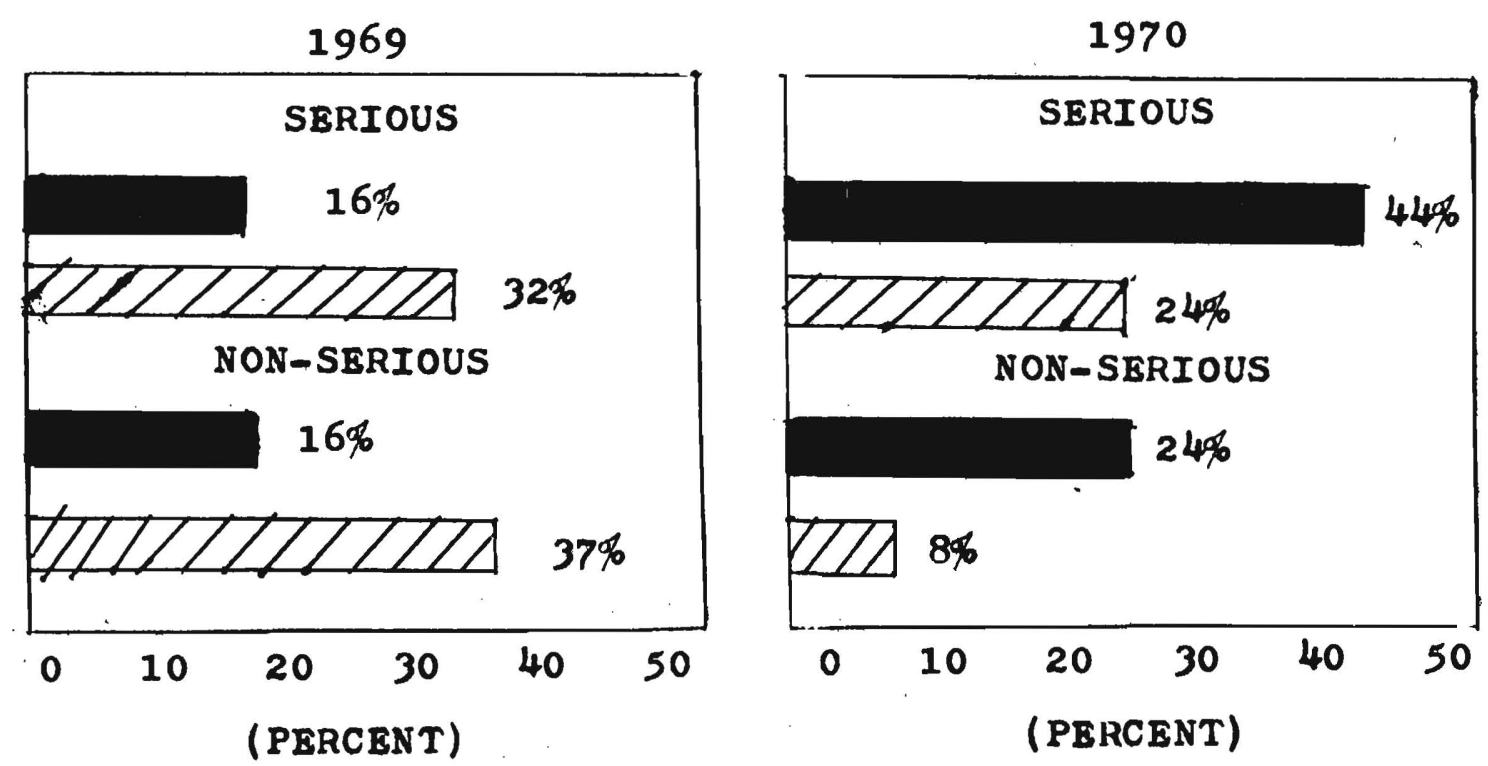

$=$ IMPROVED

PZZZ = NOT IMPROVED

Whether this would hold true in other studies is, of course, not certain. Full social data on the families of the study groups were not available on all the cases so correlations were not possible in many areas; but since the early part of 1970, a complete social history has been obtained on each family with specific information included. An analysis of this data at a later time may prove very valuable in the future. 


\section{SUMMARY}

The child abuse and neglect picture definitely shows a trend toward improvement in the 1970 calendar year. More of the study families are receiving agency help and a greater percentage of them are improving their situation. Certainly the cases seen from both years have many of the same problems and circumstances. The improvement trend seems tied to the timeiy intervention by the proper authorities with subsequent follow up help being provided to the youngsters and their families.

Improvement in the 1970 study cases appears to be related to both the intervention and "follow through" of the Child Abuse Committeo. Many of the 1969 cases should have had better service from the committee but since some never reached the agenda, nothing was done about them. Most certainly the case previously referred to with repeated suspected batterings from 1966, 1967, 1968, and 1969 should have had "follow through" but did not and its present situation is unknown. Also, the youngster with the scrotum injury deserved to have the situation closely examined before returning him home, but this did not happen and we simply don't know what has happened to him. The chances of such incidences happening now are slight under the present set-up of the committee. They not only refer cases to the community resources, but 
keop checking to see that the family receives the needed help.

Some families will never be able to substantially change their inadequate way of functioning in spite of all the help they receive; for these families it is our moral obligation to at least provide the children with protection of their Iives not subjected to permanent damage or even death. 11 Parents have a right to their children but children have a right to 1ive.

One of the greatest problems in providing these protective services to the children is the lack of co-ordination between the agencies doing the work. The question of who has the authority and the responsibility in each case has often led to duplication of service to some and lack of it to others. Instead of co-ordinating their efforts, the agencies have too often been working against each other.

In an attempt to provide a concrete way of protecting the children they see, the Child Abuse Committee has frequent1y worked out what they see as a reasonable plan, and then utilized the community resources to carry it through. Now quite often the committee acts as the co-ordinating agency; motivating some of the resource agencies to become involved, and then keoping track of the outcome. In theory it seoms quite reasonable, but there are problems which develop. The committoe actualiy has no authority to do this co-ordinating; and even more of a problem, the individual person within the

11 Brown and Daniels, op cit., 94; Zalba, op cit., 70. 
agency responsible for carrying out the plan, may not share the committer's concern.

A rather startiling example of this was the case of a six month old girl admitted in February of 1970 for "failure to thrive", emotional deprivation, and multiple bruises-her weight was only 8 pounds. She was hospltalized for one month, during which time she made excellent gains and the parents were counseled in how to care for and feed the baby. They were an extremely hostile couple, very alienated from society, with multiple problems. In June the child was brought into the out-patient clinic with an eye injury and considerable weight 1oss. When the doctors recommended hospitalization the mother refused and removed the child against medical advice. The child was next seen in July 1970 when she was transferred to this hospital by the sheriff's office with a 1ip injury, multiple bruises and abrasions and malnutrition. Her weight at 11 months was just $9 \frac{1}{2}$ pounds.

The Juvenile Court was contacted and the youngster was held first in the hospital and then foster care until a hearing was held. The court ordered the child be held in care until the parents demonstrated to the Welfare Department that they were able to parent this child properly. With all this information available to him, the welfare casoworker returned the child to her parents in just four weeks; because, according to his priority, it was more important that the parents 1ike him and see him as helpful to them. The child has been home since October, but the parents steadrastly refuse to bring the child back to be medioally ohecked. 
The comittee is now requesting that the Jurenile Court review this case and, if necessary, force these parents to have the child examined and provided with any neoessary medical care.

\section{$++++$}

The need is quite evident. If a comprehensive program of delivering protective services to children is to be really workable, the responsibility must be placed with one agency. The job of directing the services to these children and their families and getting them to utilize them must, by logic, carry the authority to do so. 12 Without either the authority or the responsibility, the Child Abuse Committee has attempted to fill the gap.

\section{2}

Paul V. Nyden, "The Use of Authority", Public Welfare: Shankar Yelaja, op cit. 


\section{A SELECTED BIBLIOGRAPHY}

Berlow, Leonard. "Recognition and Rescue of the Battered Child", J.A.H.A., Vol. 41, January 1967.

Boardman, Helen E. "A Project to Rescue Children from Inflicted Injury", Social Work, Vo1. 7 No. 1, January 1962 .

Brieland, Donald. "Protective Services and Child Abuses Implications for Public and Child Welfare", Social Service Review, Vol. 40 No. 4, 1966.

Brown, John A. and Robert Daniels. "Some Observations on Abusive Parents", Child Welfare, Vol. 47 No. 2, 1968.

Davies, Joann. "When the Agency Must Intervene", Pub11c Welfare, Vol. 23 No. 2, 1965.

DeFrancis, Vincent. Lets Get Technical, "The 'Why and What' of Child Protective Services", The American Human Association, (Childrens Division), Denver, Colorado, 1958.

Elmer, Elizabeth. "Hazards in Determining Child Abuse", Child Welfare, Vol. 45 No. 1, January 1966.

Fontana, Vincent J., M.D. "An Insidious and Disturbing Medical Entity", Public Welfare, Vol. 24 No. 3, 1966.

Hancock, Claire. Children and Neglect, "....Hazardous Home Conditions", U. S. Department of Health, Education and Welfare, Washington D.C., 1963.

Helfer, Ray E., M.D. and C. Henry Kempe, M.D., eds. The Battered Child, University of Chicago, Chicago, 1968.

Herre, Ernest A. "A Community Mobilizes to Protect its Children", Public Welfare, Vol. 24 No. 3, 1966.

Herre, Ernest A. "Aggressive Casework in a Protective Services Unit", Social Casework, Vol. XLVI No. 6, 1965.

Johnson, Betty and Harold A. Morse. "Injured Children and Their Parents", Children, Vol. 15 No. 4, 1968.

Massing, Rose. "Neglected Childrens A Challenge to the Community, Social Work, Vol. 3, April 1958. 
Morris, Marian G. and Robort W. Gould and Patricia Matthews. "Towards Prevention of Child Abuse", Children, Vol. 2 No. 2,1964 .

Morse, Carole W., Jane Z. Sahler and Stanford B. Friedman, M.D. "A Three Year Follow Up Study of Abused and Neglected Children", American Journal of Diseases of Children, Vo1. 120, November 1970.

Myklebust, Betty J. Childrens Protective Services 1964-1966-A Way of Hearing, Medina Childrens Services, Seattle, 1966.

Nyden, Paul V. "The Use of Authority", Public Welfare, Vol. 24 No. 3, 1966.

Paulsen, M. G. "Legal Protections Against Child Abuse", Children, Vol. 13 No. 2, 1966.

Paulson, Morris J. and Phillip R. Blake. "The Physically Abused Child--A Focus on Prevention", Child Welfare, Vo1. XIVII No. 2, 1966.

Rubin, Jean. "The Need for Intervention", Public Welfare, Vol. 24 No. 3, 1966.

Stringer, Elizabeth. "Homemaker Service in Neglect and Abuse: A Tool for Case Evaluation", Children, Vol. 12 No. 1 , January 1965.

Williams, Fredricks D. "The AFDC Workers Role in Protective Services", Child Welfare, Vol. 48 No. 5, 1969.

Yelaja, Shankar A. "The Concept of Authority and Its Use in Protective Services", Child Welfare, Vol. 44 No.9, 1965.

Young, Leontine. "An Interim Report on An Experimental Program of Protective Service", Child Welfare, Vol. 45 No. 7, 1966.

Young, Leontine. Wednesday's Children, McGraw-Hill Book Co., Now York, 1964.

Zalba, Serapio R. "The Abused Child: A Typology for Classification and Treatment", Social Work, Vol. 12 No. 1 , 1967. 